\title{
High abrupt cord termination: a hallmark of caudal regression syndrome
}

\author{
Kadalur Thimmegowda Puneeth, Ankur Goyal, Manisha Jana
}

Department of Radiodiagnosis, All India Institute of Medical Sciences (AllMS), New Delhi, India

\section{Correspondence to}

Ankur Goyal,

ankurgoyalaiims@gmail.com

\section{CrossMark}

To cite: Puneeth $\mathrm{KT}$ Goyal A, Jana M. BMJ Case Rep Published online: [please include Day Month Yearl doi:10.1136/bcr-2013201770

\section{DESCRIPTION}

A 10-month-old female infant, born to a diabetic mother, presented with dribbling of urine since birth. Physical examination was unremarkable. Plain radiograph of lower spine showed partial sacral agenesis. MRI of the spine (figure 1) revealed sacrococcygeal hypoplasia (dysplastic $\mathrm{S}_{4}$ vertebra and absent $S_{5}$ and coccyx). Conus medullaris was blunt ending, club-shaped and terminated at $\mathrm{L}_{1}$ vertebral level. The caudal nerve roots were arranged in anterior and posterior bundles. No associated syrinx was seen. Imaging findings were characteristic of caudal regression syndrome type 1 .

Caudal regression syndrome designates a constellation of anomalies resulting from insult in the early stages of gestation. Although uncommon in the general population, there is a 200 -fold increase in the incidence in infants of diabetic mothers, where 1 in 350 newborns is affected. ${ }^{1}$ One per cent of infants born to diabetic mothers will have a form of this syndrome, and $16 \%$ of infants with the syndrome have diabetic mothers. ${ }^{2}$ The spectrum of clinical presentation and caudal structural defects varies from being asymptomatic to extensive. Motor involvement is common and deficits correspond to the level of vertebral agenesis. In type 1 , there is abnormally high abrupt termination of the conus, while in type 2 , the cord is low-lying and tethered. Club-shaped or wedge-shaped appearance of the conus with double-bundle arrangement of the caudal nerve roots is typical of type $1 .^{3}{ }^{4}$ Type 1 is associated with major sacral dysgenesis and urinary and bladder dysfunction.
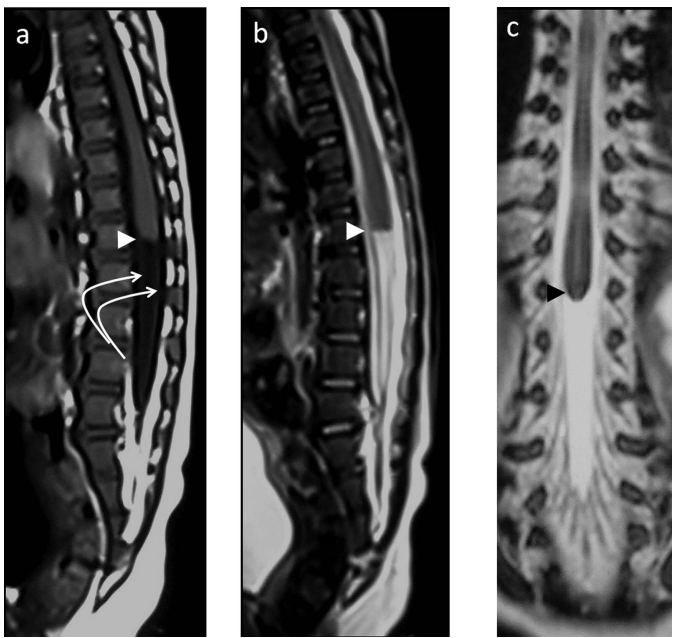

Figure 1 Sagittal T1-weighted (A), T2-weighted (B) and coronal T2-weighted (C) MRI showing abrupt club-shaped termination of the conus medullaris (arrowheads) with double-bundle arrangement of nerve roots (curved arrows). There is a partial sacral agenesis.
Large sacral motor deficit occurs, while sensations are relatively preserved. Severe neurological disturbances and deterioration are common in type $2 .{ }^{5}$ Associated cardiopulmonary, genitourinary and gastrointestinal malformations must be looked for and managed accordingly. The prognosis depends on the severity of the defect and presence of associated abnormalities. Surviving infants usually have normal mental function but require extensive urological and orthopaedic assistance. ${ }^{6}$ Prenatal sonographic diagnosis is possible but findings are variable depending on the severity of defect. Small crown-rump length in the first trimester and short spine with missing lumbosacral vertebrae later in pregnancy can suggest the diagnosis. ${ }^{67}$

\section{Learning points}

- Abnormally high club-shaped abrupt termination of the cord with sacral deformities is a hallmark of caudal regression syndrome type 1.

- In type 2, the spinal cord is low-lying and tethered.

- Bladder and anorectal problems, neurological deficits and clinical/radiographical evidence of sacral dysgenesis should raise the suspicion of caudal regression syndrome, especially in infants of diabetic mothers.

Contributors All authors have contributed equally to the design and construction of the case report.

\section{Competing interests None.}

Patient consent Obtained.

Provenance and peer review Not commissioned; externally peer reviewed.

\section{REFERENCES}

1 Mills JL. Malformations in infants of diabetic mothers. Teratology 1982;25:385-94.

2 Passarge $E$, Lenz W. Syndrome of caudal regression in infants of diabetic mothers: observations of further cases. Pediatrics 1966;37:672-5.

3 Barkovich AJ, Raghavan N, Chuang S, et al. The wedge-shaped cord terminus: a radiographic sign of caudal regression. AJNR Am J Neuroradiol 1989;10:1223-31.

4 Nievelstein RA, Valk J, Smit LM, et al. MR of the caudal regression syndrome: embryologic implications. AJNR Am J Neuroradiol 1994;15:1021-9.

5 Pang D. Sacral agenesis and caudal spinal cord malformations. Neurosurgery 1993;32:755-79.

6 Adra A, Cordero D, Mejides A, et al. Caudal regression syndrome: etiopathogenesis, prenatal diagnosis, and perinatal management. Obstet Gynecol Sur 1994;49:508-16.

7 González-Quintero VH, Tolaymat L, Martin D, et al. Sonographic diagnosis of caudal regression in the first trimester of pregnancy. J Ultrasound Med 2002;21:1175-8. 
Copyright 2014 BMJ Publishing Group. All rights reserved. For permission to reuse any of this content visit http://group.bmj.com/group/rights-licensing/permissions.

BMJ Case Report Fellows may re-use this article for personal use and teaching without any further permission.

Become a Fellow of BMJ Case Reports today and you can:

- Submit as many cases as you like

- Enjoy fast sympathetic peer review and rapid publication of accepted articles

- Access all the published articles

- Re-use any of the published material for personal use and teaching without further permission

For information on Institutional Fellowships contact consortiasales@bmjgroup.com

Visit casereports.bmj.com for more articles like this and to become a Fellow 